\title{
Senyawa Antibakteri Escherichia coli ATCC 35218 dan Staphylococcus aureus ATCC 25923 dari Kapang Endofit Taman Nasional Gunung Halimun
}

\author{
Ruth Melliawati $\left.{ }^{\star}\right)$ dan Harni \\ Pusat Penelitian Bioteknologi LIPI, JI. Raya Bogor KM. 46 Cibinong \\ Diterima 13-03-2009 Disetujui 03-08-2009
}

\begin{abstract}
Endophytic fungus is a microorganism which live in the interstitial spaces healthy tissues of the host plant, and has capability to produce secondary metabolite such as micotoxin, antibiotic and antiviral. This research was aimed to find out the isolates of endophytic fungus produce antibacterial compounds to inhibit Escerichia coli ATCC 35218 and Staphylococcus aureus ATCC 25923, and to investigate the Retention time (Rt) of the antibacterial compounds produced by endophytic fungus with High Performance Liquid Chromatography (HPLC) methods. Diffusion Agar Plate Method was used to examine the antibacterial compounds on Escerichia coli ATCC 35218 and Staphylococcus aureus ATCC 25923. While the antibacterial compounds were examined with Thin Layer Chromatography (TLC) and High Performance Liquid Chromatography (HPLC) methods, and the result were compared with Chloramphenicol and Ampicillin antibiotic standart. Two isolates of endophytic fungus namely HI.46F.211 and HL.57F.258 were inhibited the growth Escherichia coli ATCC 35218 and three isolates namely HL.48F217, HL.53F.243 and HL.57F.258 showed antagonistic action against Staphylococcus aureus ATCC 25923. The results of TLC and HPLC analysing method show that antibacterial compounds produced by endophytic fungus HL.46F.211 had Rt (Retention Time) rate similar with antibiotic Chloramphenicol at 2,796 (at water fraction) and Rt antibiotic Amphycillin at 2,662 (at Chloroform fraction). While antibacterial compounds produced by endophytic fungus HL.57F.258 had Rt rate similar with antibiotic Amphycillin at 2,650 (at Chloroform fraction).
\end{abstract}

Keywords: Endophytic fungus, Gunung Halimun National Park, selection, antibacterial, HPLC.

\section{PENDAHULUAN}

Alam tropis Indonesia menyimpan kekayaan alam yang begitu beraneka ragam, baik flora, maupun faunanya. Keanekaragaman mikrobiologisnya pun sangat melimpah (Handayani, 2004). Berbagai jenis mikroorganisme terutama mikroorganisme endofitnya berpotensi, tetapi belum banyak dimanfaatkan untuk kesejahteraan masyarakat (Kahono \& Amir, 2002).

Sementara itu, dengan berkembangnya ilmu dan teknologi, maka semakin berkembang pula pengetahuan tentang penyakit dan pengendaliannya. Sampai saat ini penyakit infeksi pada manusia yang disebabkan oleh mikroorganisme patogen, merupakan permasalahan kesehatan yang cukup serius dan pengobatan dilakukan dengan pemberian antibiotik. Hasil penelitian Neneng, (2000), melaporkan bahwa pemakaian antibiotik dapat menyebabkan mikroorganisme patogen menjadi resisten. Selain resisten juga mengalami mutasi (Brooks et al., 2001). Bakteri yang meningkat kekebalannya terhadap

\footnotetext{
*Telp: +6285691083634

Email: ruthmell2000@yahoo.com
}

antibiotik antara lain Escherichia coli dan Klebsiella pneumonia. Tingkat kekebalan kedua bakteri ini meningkat 2-3 kali lipat sejak tahun 1997. Sedang Escherichia coli kekebalannya meningkat dari 19\% menjadi 32\% terhadap antibiotik pada tahun 1997. Di Indonesia diketahui ada sekitar 23 jenis bakteri Escherichia coli dan 33 Klebsiella pneumonia yang kebal terhadap antibiotik. Sementara itu menurut Tjay (2002) sejak akhir tahun 1980-an muncul berbagai kuman dari kelompok Staphylococcus yang resisten terhadap penisillin. Sanglard (2001) dan Bonjar et al., (2004) menyampaikan bahwa jumlah dan jenis infeksi terhadap manusia semakin luas, zat antimikroba semakin berspektrum sempit sehingga hanya efektif untuk jenis patogen tertentu saja dan ada kecenderungan resistensi mikroba hanya terhadap zat antimikroba tertentu saja.

Salah satu mikroorganisme penghasil antibiotik yang mulai banyak diteliti sekarang ini adalah kapang endofit yang terdapat di dalam sistem jaringan tumbuhan, seperti daun, batang, bunga, ranting atau pun akar tumbuhan (Clay, 1988). Kapang endofit ini menginfeksi tumbuhan sehat pada jaringan tertentu 
tanpa menimbulkan gejala yang tampak sebagai penyakit (Bills, 1996; Tan \& Zau, 2001; Faeth, 2002), dan mampu manghasilkan senyawa metabolit sekunder seperti mikotoksin, enzim dan antibiotik (Carrol, 1988; Clay, 1988). Banyak kelompok kapang endofit mampu memproduksi senyawa antibiotik yang aktif melawan bakteri maupun fungi patogenik terhadap manusia, hewan dan tumbuhan, terutama dari genus Coniothirum dan Microsphaeropsis (Petrini et al., 1992).

Untuk mengatasi permasalahan tersebut, maka perlu dicari senyawa aktif baru yang mampu membasmi bakteri patogen. Oleh karena itu dalam penelitian ini dilakukan seleksi terhadap 29 isolat kapang endofit yang berasal dari Taman Nasional Gunung Halimun, sebagai sumber pencarian senyawa aktif baru, dengan tujuan untuk mendapatkan senyawa aktif antibakteri Escherichia coli ATCC 35218 dan Staphylococcus aureus ATCC 25923 (kedua bakteri ini sangat erat hubungannya dengan bagian dalam tubuh manusia).

\section{BAHAN DAN METODE}

Mikroorganisme. Kapang endofit yang digunakan sebanyak 29 isolat yang berasal dari 9 sampel tumbuhan berkhasiat obat di Taman Nasional Gunung Halimun (TNGH) Jawa Barat. Isolat tersebut merupakan koleksi Puslit Bioteknologi LIPI Cibinong. Mikroorganisme uji yang digunakan adalah Escherichia coli ATCC 35218 dan Staphylococcus aureus ATCC 25923. Kedua bakteri ini merupakan kelompok bakteri enteropatogenik yang telah resisten terhadap antibiotik penisillin (Salle, 1961). diperoleh dari Laboratorium Mikrobiologi Fakultas Kedokteran Universitas Sebelas Maret Surakarta.

Seleksi kapang potensial. Seleksi kapang endofit penghasil senyawa antibakteri dilakukan dengan metode difusi agar padat (Diffusion Agar Plate Method). Bakteri uji sebanyak $1 \mathrm{~mL}$ diinokulasikan ke dalam cawan Petri dan tambahkan medium Nutrient agar cair yang tidak terlalu panas sebanyak $15 \mathrm{ml}$ kemudian dihomogenkan dengan cara digoyang dan dibiarkan sampai dingin. Setelah medium padat, potongan kapang endofit (berdiameter $6 \mathrm{~mm}$ ) yang akan diseleksi ditempelkan diatas permukaan medium, selanjutnya diinkubasikan selama 2-3 hari pada suhu kamar (28$30^{\circ} \mathrm{C}$ ). Pengamatan dilakukan dengan mengukur diameter zona hambat di sekitar kapang endofit (Desriani et al., 2004; Strobel et al., 2001). Luas zona hambat dihitung dengan rumus dalam Sukara et al., (1992).
Fermentasi.Kapang endofit yang terseleksi positif menghasilkan zona hambat, dilarutkan dengan $5 \mathrm{ml}$ aquades steril. Tiga persen cairan spora/misellium kapang endofit tersebut diinokulasikan ke dalam 300 $\mathrm{ml}$ Potato Dextrose Broth dan diinkubasi selama 5 hari dalam inkubator shaker dengan kecepatan $150 \mathrm{rpm}$ pada suhu kamar $28-30^{\circ} \mathrm{C}$ (Castillo et al., 2002; Simanjutak et al., 2002).

Analisis. Analisis dilakukan menggunakan Kromatografi Lapis Tipis (Stahl, 1969), spot yang terditeksi ditentukan nilai $\mathrm{Rf}$ nya dgn rumus dalam Khopkar (1990). Analisis selanjutnya menggunakan Kromatografi Cair Kinerja Tinggi (KCKT) menurut Gritter et al., (1990) dan sebagai eluen disiapkan Kloroform : Methanol (2:4) dan (4:2), larutan standar yang digunakan antibiotik Kloramfenikol dan Ampisillin.

\section{HASIL DAN PEMBAHASAN}

Seleksi kapang endofit terhadap mikroba patogen. Dua puluh sembilan (29) isolat kapang endofit yang berasal dari 9 jenis tumbuhan yang berhasiat obat diseleksi. Hasil seleksi diperoleh, 2 isolat kapang endofit positif menghambat pertumbuhan Escherichia coliATCC 35218 dan 3 isolat terhadap Staphylococcus aureus ATCC 25923.(Tabel 1).

Menurut Holler (1999) bila suatu senyawa dapat membentuk zona hambat $\geq 3,14 \mathrm{~mm}^{2}$, maka senyawa tersebut positif menghambat pertumbuhan mikroorganisme uji. Kapang endofit HL.46F.211 dan HL.57F.258 positif menghambat pertumbuhan bakteri Escherichia coli ATCC 35218. Sementara kapang endofit HL.48F.217, HI.53F.243 dan HL.57F.258 positif menghambat pertumbuhan Staphylococcus aureus ATCC 25923. Daya hambat isolat kapang HL46F.211 terhadap E. coliATCC 35218 diperlihatkan pada Gambar 1 A dan. HI.53F.243 terhadap S. aureus ATCC 25923 pada Gambar 1 B. Isolat kapang HL.57F.258 mampu menghambat kedua bakteri uji, sehingga kapang tersebut dikatagorikan mempunyai spectrum luas karena dapat menghambat dua bakteri uji sekaligus, sementara itu isolat yang lain hanya dapat menghambat satu bakteri uji saja dan dikelompokan ke dalam kelompok antibiotik berspektrum sempit (Tjay. 2002).

Menurut Brook et al., (2001) bakteri Escherichia coli ATCC 35218 dan Staphylococcus aureus ATCC 25923 sudah resisten terhadap antibiotik terutama kelompok antibiotik $\beta$-laktam. Resistensi kedua bakteri 


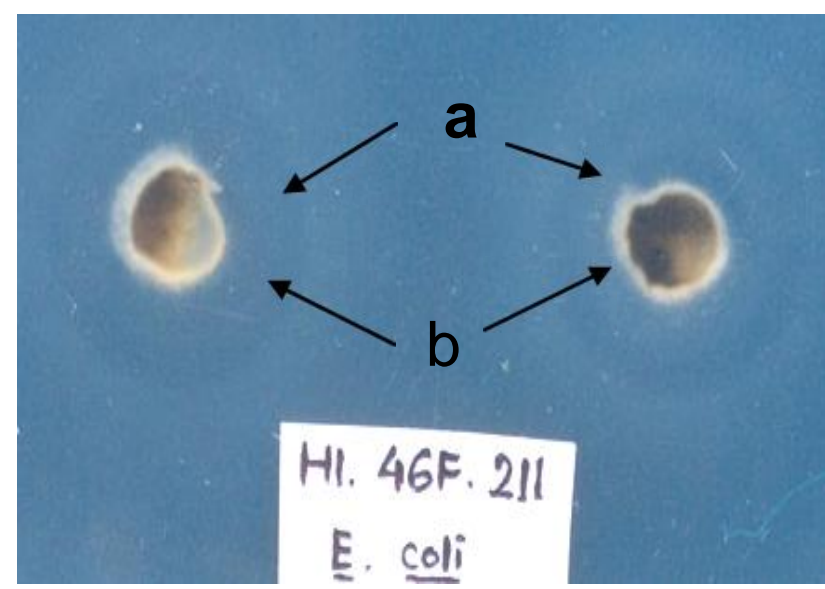

A

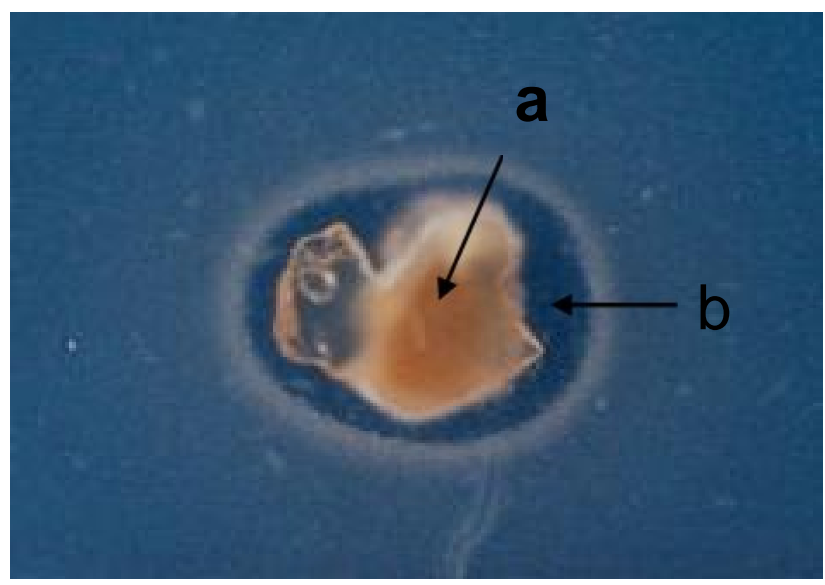

B

Gambar 1. Zona hambat kapang endofit HL.46F.211 terhadap Escherichia coli ATCC 35218 (A) dan HL.57F.243 terhadap Staphylococcus aureus ATCC 25923 (B) a. Zona jernih b. Kapang endofit

Tabel 1. Hasil uji kapang endofit terhadap Escherichia coli ATCC 35218 dan Staphylococcus aureus ATCC 25923 (dari 29 isolat)

\begin{tabular}{cccc}
\hline \multirow{2}{*}{$\begin{array}{c}\text { No } \\
\text { Isolat }\end{array}$} & Kode Isolat & \multicolumn{2}{c}{ Zona Hambat terhadap } \\
\cline { 3 - 4 } & & $\begin{array}{c}\text { E. coli ATCC } \\
35218\end{array}$ & $\begin{array}{c}\text { S. aureus ATCC } \\
25923\end{array}$ \\
\hline 17. & HL.46F.211 & +++ & - \\
20. & HL.48F.217 & - & + \\
25. & HL.53F.243 & - & + \\
26. & HL.57F.258 & ++ & +++ \\
\hline
\end{tabular}

Keterangan :+ $\quad$ :Terbentuk zona jernih $(7 \leq \mathrm{d} \leq 10 \mathrm{~mm})$ $++\quad$ :Terbentuk zona jernih $(11 \leq \mathrm{d} \leq 14 \mathrm{~mm})$ $+++\quad$ :Terbentuk zona jernih $(\mathrm{d} \geq 15 \mathrm{~mm})$

tsb disebabkan karena bakteri tsb memproduksi enzim $\beta$-laktamase, enzim ini dapat memotong cincin $\beta$ laktam sehingga aktivitas antibiotik tersebut menjadi hilang. Menurut Neneng (2000) bakteri Escherichia coli ATCC 35218 diketahui sebagai bakteri yang mampu menghasilkan enzim $\beta$-laktamase Tipe TEM-1, sehingga bakteri ini resisten terhadap antibiotik kelompok $\beta$-laktam. Jadi, senyawa antibakteri yang dihasilkan oleh kapang endofit yang menghambat pertumbuhan kedua bekteri uji ini merupakan senyawa antibiotik yang tahan terhadap aktivitas enzim $\beta$ laktamase.

Pola Pertumbuhan Kapang Endofit Potensial. Dalam penelitian ini 2 kapang endofit (HL.46F.211 dan HL.57F.258) terpilih untuk penelitian lebih lanjut, karena kedua kapang tersebut mempunyai kemampuan dalam menghambat pertumbuhan bakteri uji, dengan menunjukkan hasil zona hambat yang luas (Tabel 1), yaitu masing masing terhadap E. Coli dan S. aureus. Senyawa aktif akan diproduksi dari kedua kapang tersebut namun sebelumnya dicari lebih dulu pola pertumbuhan dari masing masing kapang tersebut untuk mendapatkan informasi waktu yang tepat pada proses fermentasi dan pemanenan. Hal ini menjadi penting karena senyawa metabolit sekunder dihasilkan pada saat akhir fase logaritmik atau awal fase stasioner. Pada fase ini terjadi akumulasi senyawa metabolit sekunder pada medium fermentasi (Ingrahman, 2000).

Langkah selanjutnya yang harus segera dilakukan adalah recovery, yaitu upaya memanen senyawa antibiotik (metabolit sekunder) sebelum terjadi autolisis misellium yang mengakibatkan penurunan pertumbuhan dan autolisis sel yang dapat mengakibatkan rusaknya antibiotik (El Sayed, 1994). Pola pertumbuhan kapang endofit HL.46F.211 dan HL.57F.258 diperlihatkan pada gambar 2 dan 3. Dari Gambar 2 dapat diketahui bahwa, fase adaptasi kapang endofit HL. 46F.211 dimulai pada hari ke-0 sampai hari ke-1. Pada fase ini terjadi penyesuaian diri kapang endofit pada lingkungan barunya. Pada fase ini belum terjadi pembelahan sel melainkan terjadi pertambahan ukuran atau besar sel. Selanjutnya masuk fase permulaan pembiakan (hari ke-1-2). Fase berikutnya adalah fase pembiakan cepat (fase Logaritmik/ fase eksponensial), yaitu terjadi pada hari ke-2 sampai hari ke 4 tetapi pada hari ke 4 terlihat populasi menurun, hal ini kemungkinan terjadi kesalahan dalam pengambilan sampel (hari ke 4) yang kurang homogen sehingga populasi menurun.

Pertambahan jumlah sel mengikuti kurva logaritmik. Berakhirnya fase ini, kemudian diikuti fase pembiakan diperlambat (hari ke 4-5). Pada fase ini pembelahan sel mulai melambat, sehingga jumlah sel yang hidup hampir sama dengan sel yang mati, karena dipengaruhi jumlah nutrisi yang mulai habis. Akhir fase logaritmik atau memasuki fase stasioner merupakan saat metabolit sekunder mulai dihasilkan dengan titik 


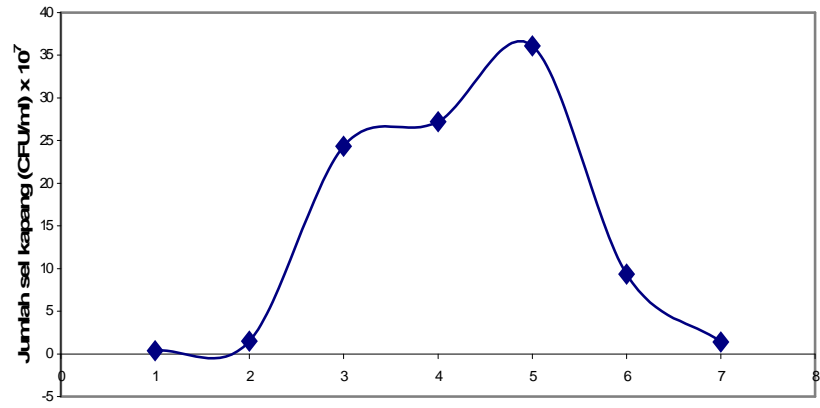

Lama fermentasi (hari)

Gambar 2. Grafik pola pertumbuhan kapang endofit HL.46F.211

pertumbuhan kultur sel tertinggi, seperti ditunjukkan pada gambar 2. Pada hari ke-5 sel mencapai jumlah tertinggi yaitu $3,61 \times 10^{8} \mathrm{CFU} / \mathrm{mL}$, sehingga hari ke-5 adalah waktu yang tepat untuk memanen senyawa antibiotik, karena diduga pada saat sel mencapai jumlah yang tertinggi diperkirakan senyawa metabolit sekunder yang terakumulasi juga mencapai maksimal (Simanjutak et al., 2002). Pada Gambar 3, pola pertumbuhan kapang endofit HL.57F.258 tidak jauh berbeda dan diketahui pada hari ke- 5 merupakan waktu yang tepat untuk memanen senyawa antibakteri pada proses fermentasi karena jumlah sel mencapai nilai tertinggi yaitu $2,40 \times 10^{8} \mathrm{CFU} / \mathrm{mL}$.

Pengukuran $\mathrm{pH}$ juga dilakukan, pada awal dan akhir fermentasi. Derajat keasaman $(\mathrm{pH})$ awal medium kultur kapang endofit HL.46F.211 adalah 5,63 kemudian terjadi kenaikan $\mathrm{pH}$ yaitu menjadi 7,19. Pada kultur kapang endofit HL.57F.258 juga terjadi kenaikan dari 5,67 menjadi 7,23 . Peningkatan nilai $\mathrm{pH}$ terjadi karena senyawa asam yang terakumulasi dalam medium dimanfaatkan oleh sel sebagai sumber energi selama sporulasi (Benoit et al., 1990 dalam Simanjutak et al., 2002). Selain itu, kenaikan pH mungkin juga disebabkan karena terakumulasinya bahan-bahan alkali dalam medium (Simanjutak et al., 2002). Menurut El-Sayed (1994) kisaran $\mathrm{pH}$ yang diperlukan untuk produksi penisillin (antibiotik) berkisar antara 5 sampai 7,5. Sementara $\mathrm{pH}$ medium hasil fermentasi oleh kedua kapang masuk dalam kisaran tersebut sehingga kemungkinan cocok untuk pertumbuhan kapang endofit dan untuk produksi senyawa antibiotik.

Fermentasi dan ekstraksi kapang endofit. Fermentasi dilakukan pada kedua kapang endofit terseleksi (HL.46F.211 dan HL.57F.258). Senyawa bioaktif (metabolit sekunder) diharapkan dapat dikeluarkan secara ekstraseluler ke dalam medium fermentasi. Senyawa aktif dapat dihasilkan secara

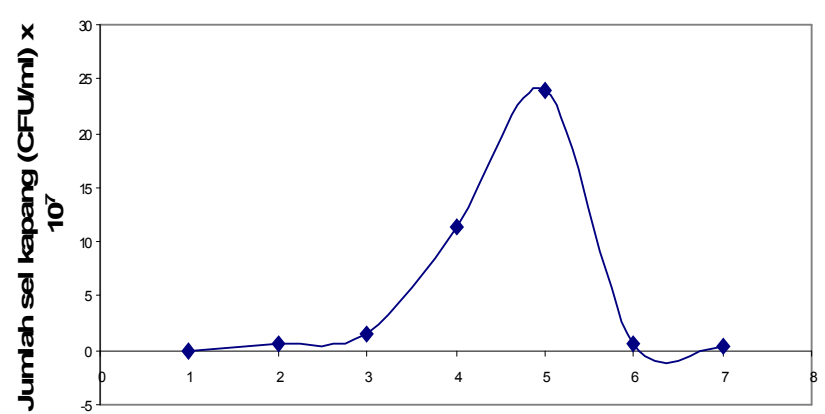

Lama fermentasi (hari)

Gambar 3. Grafik pola pertumbuhan kapang HL.57F.258

optimal apabila faktor aerasi, suhu, $\mathrm{pH}$ medium dan ketersediaan nutrisi cukup untuk pertumbuhan kapang endofit selama proses fermentasi, demikian juga bahan-bahan organik seperti karbon, nitrogen, dan mineral yang dibutuhkan oleh kapang endofit untuk biosintesis. Seperti yang dilaporkan oleh Madigan et al., (2000) bahwa akumulasi pembentukan antibiotik penisillin terjadi secara optimum apabila medium mengandung sumber karbon, nitrogen, mineral dan prekursor. Dalam penelitian ini digunakan Corn-steep liquor untuk memenuhi kebutuhan tersebut.

Isolasi senyawa antibakteri dilakukan dengan cara ekstraksi menggunakan kloroform. Ekstraksi dilakukan sebanyak tiga kali agar senyawa aktif yang diinginkan terekstrak sempurna di dalam pelarut kloroform (Houghton \& Raman, 1998 dalam Simanjutak et al., 2002). Setiap kali ekstraksi, dilakukan inkubasi dengan tujuan untuk penjenuhan. Penjenuhan dilakukan untuk menyediakan semacam jembatan agar terjadi pemindahan senyawa metabolit sekunder (antibakteri) ke dalam fase kloroform (El Sohly et al., 1990 dalam Simanjutak et al., 2002). Sehingga akan terbentuk dua lapisan yang berbeda. Hasil ekstraksi berupa ekstrak fase kloroform dan ekstrak fase air (medium). Ke dua ekstrak di evaporasi untuk mendapatkan ekstrak kering.

Analisis senyawa antibakteri melalui Kromatografi Lapis Tipis. Kromatografi merupakan metode pemisahan senyawa, dalam suatu campuran berdasarkan berat molekulnya. Hasil perbandingan yang tepat antara eluen kloroform : methanol adalah $4: 2$ dan $2: 4$. Sebagai antibiotik standar menggunakan Kloramfenikol dan Ampisillin.

Hasil uji KLT terhadap ekstrak kapang endofit HL.46F.211 pada fase kloroform (a) dan fase air (b) menunjukkan indikasi positif (Gambar 4). Ekstrak fase kloroform mempunyai nilai $\mathrm{Rf}$ yang mendekati nilai $\mathrm{Rf}$ Kloramfenikol $(0,84)$ dan Ampisillin $(0,76)$, sedangkan 


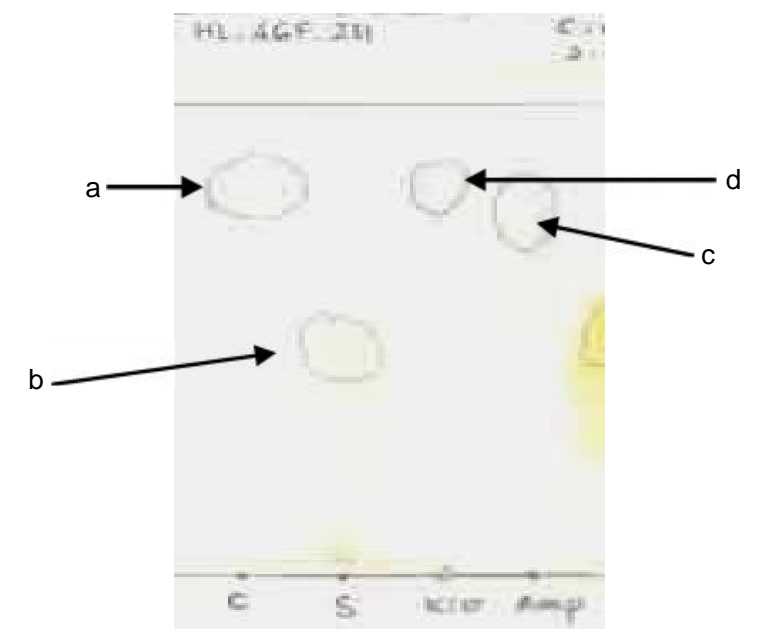

Gambar 4. Hasil KLT ekstrak kapang endofit HL.46F.211 pada si lika gel F254.
a. Spot ekstrak fase kloroform
b. Spot ekstrak fase air
c. Spot Kloramfenikol
d. Spot Ampisilin

ekstrak fase air belum dapat terangkat sempurna karena diduga ekstrak fase air tercampur dengan senyawa metabolit lain yang terdapat dalam kultur fermentasi. Hasil identifikasi menunjukkan positif pada ekstrak fase kloroform hanya memiliki atau menunjukkan noda tipis.

Noda pada masing-masing ekstrak dan antibiotik standar hanya terdeteksi dibawah sinar UV dengan panjang gelombang $254 \mathrm{~nm}$. Senyawa tersebut tampak sebagai bercak/ noda gelap pada latar belakang yang berfluoresensi kuning-hijau. Setelah disemprot dengan penapak bercak $\mathrm{CeSO}_{4}$ (Cerium Sulfat) warna noda yang terbentuk ungu.

Analisis KLT terhadap ekstrak fase kloroform dan fase air kapang endofit HL.57F.258 juga menunjukkan hasil positif (Gambar 5), yaitu contoh uji mempunyai kisaran nilai $\mathrm{Rf}$ mendekati $\mathrm{Rf}$ antibiotik standar Kloramfenikol $(0,84)$ dan Ampisillin $(0,76)$. Sementara itu hasil positif pada ekstrak fase air hanya memiliki noda tipis. Noda tipis tersebut mengindikasikan bahwa senyawa metabolit sekunder pada ekstrak kapang endofit HL.57F.258 terlarut dalam kloroform, atau senyawa metabolit sekunder tersebut bersifat non polar.

Analisis senyawa antibakteri dengan metode KCKT. Hasil analisis menggunakan KCKT diperlihatkan pada Tabel 2 dan 3. Pada kromatogram hasil analisis fraksi kloroform (HL46F211), diketahui bahwa nilai Rt senyawa tersebut terdeteksi pada menit 2,679, mendekati kisaran Rt Ampisillin pada menit 2,650. Pada kromatogram HL.46F.211(1) nilai Rt senyawa, terdeteksi

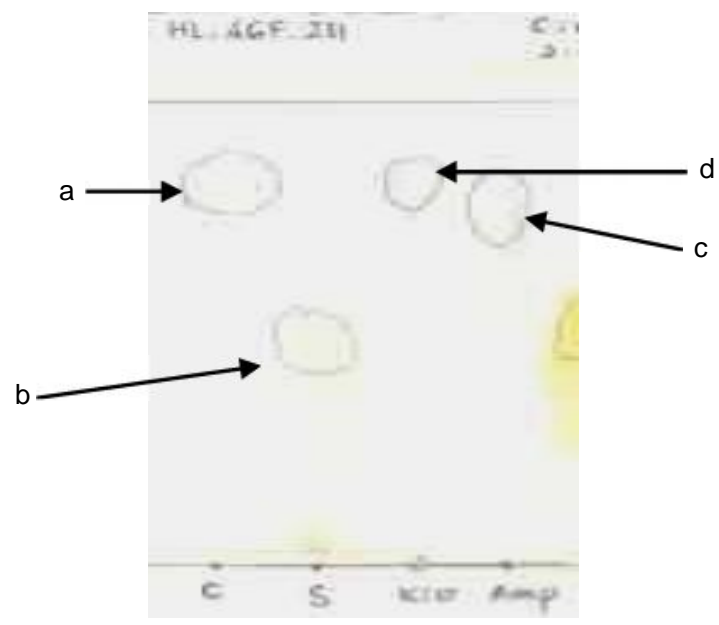

Gambar 5. Hasil uji KLT ekstrak kapang endofit HL.57F.258 pada silika gel F254
a. Spot ekstrak fase kloroform
b. Spot ekstrak fase air
c. Spot Kloramfenikol
d. Spot Ampisillin

pada menit 2,708 mendekati kisaran Rt Kloramfenikol (pada menit 2,796). Dari hasil kromatogram tersebut diketahui pula bahwa senyawa pada fraksi HL.46F.211(1) hasilnya benar-benar murni, karena Peak yang terbentuk hanya satu dengan luas area $100 \%$. Pada kromatogram HL.46F.211(2) dan HL.46F.211(3) pada fase air, nilai Rt senyawa yang terdeteksi masing masing pada menit 2,725 dan 2,792, waktu Rt nya mendekati Rt Kloramfenikol. Sehingga dari hasil tersebut dapat dikatakan bahwa ekstrak fungi endofit HI.46F.211 menghasilkan senyawa metabolit sekunder yang mendekati Kloramfenikol dan Ampisillin atau senyawa turunannya. Bila dilihat dari hasil seleksi awal, isolat HL.46F.211 dapat menghambat pertumbuhan $\mathrm{E}$. Coli $(+++)$ dan tidak menghambat pertumbuhan $\mathrm{S}$. aureus (Tabel 1) sementara hasil KCKT dari ekstrak isolat ini menunjukkan bahwa ekstrak mengandung senyawa yang mendekati Kloramfenikol dan Ampisillin. Kloramfenikol dan Ampisilin merupakan 2 macam antibiotik yang sama sama dapat membinasakan bakteri gram negatif dan positif. Jadi dari hasil tersebut dapat dikatakan bahwa senyawa aktif anti bakteri dari isolat HL.46F.211 baru terlihat setelah melalui fermentasi dan ekstraksi.

Kromatogram hasil analisis KCKT fraksi kloroform pada ekstrak HL57F.258(1) dan HL57F.258(2) serta HL.57F.258 fase air menunjukkan bahwa senyawa metabolit sekunder tersebut mempunyai waktu retensi yang kisarannya mendekati nilai Rt Kloramfenikol standar $(3,267)$, Rt masing masing adalah 3,258 dan 
Tabel 2. Hasil analisis ekstrak kapang HL.46F.211 menggunakan KCKT pada eluen Kloroform : Metanol = $2: 4$

\begin{tabular}{|c|c|c|c|c|c|}
\hline No & Kode sampel & RT & $\begin{array}{c}\text { Luas Area } \\
(\%)\end{array}$ & $\begin{array}{c}\text { Senyawa } \\
\text { pembanding }\end{array}$ & $\begin{array}{l}\text { RT Senyawa } \\
\text { pembanding }\end{array}$ \\
\hline 1 & HL.46F.211 (1) (fase air) & 2,708 & 100 & Kloramfenikol & 2,796 \\
\hline 2 & HL.46F.211 (1) (fase Kloroform) & 2,679 & 3,16 & Ampisillin & 2,650 \\
\hline 3 & HL.46F.211 (2) (fase air) & 2,725 & 82,55 & Kloramfenikol & 2,797 \\
\hline 4 & HL.46F.211 (3) (fase air) & 2,792 & 39,79 & Kloramfenikol & 2,797 \\
\hline
\end{tabular}

Tabel 3. Hasil analisis ekstrak kapang HL.57F.258 menggunakan KCKT pada eluen Chloroform : Metanol = $4: 2$

\begin{tabular}{|c|c|c|c|c|c|}
\hline No. & Kode sampel & RT & $\begin{array}{l}\text { Luas area } \\
(\%)\end{array}$ & $\begin{array}{c}\text { Senyawa } \\
\text { pembanding }\end{array}$ & $\begin{array}{l}\text { RT senyawa } \\
\text { pembanding }\end{array}$ \\
\hline 1 & HL.57F.258 (1) (fase Kloroform) & 3,258 & 25,13 & Kloramfenikol & 3,267 \\
\hline \multirow[t]{2}{*}{2} & HL.57F.258 (2) (fase Kloroform) & 3,204 & 60,45 & Kloramfenikol & 3,267 \\
\hline & & 2,829 & 23,99 & Ampisillin & 2,883 \\
\hline 3 & HL.57F.258 (3) (fase Kloroform) & 2,812 & 91,04 & Ampisillin & 2,883 \\
\hline \multirow[t]{2}{*}{4} & HL.57F.258 (fase air) & 3,254 & 14,26 & Kloramfenikol & 3,267 \\
\hline & & 2,887 & 36,09 & Ampisillin & 2,883 \\
\hline
\end{tabular}

3,204 serta 3,254. Selain itu ekstrak HL57F.258(2) dan HL57F.258(3) dari fraksi kloroform serta HL57F.258 fase air mengandung senyawa metabolit sekunder yang mendekati Rt.Ampisillin standar (2,883), yaitu masing masing 2,829, 2,812 dan 2,887 (Tabel 3). Khususnya untuk ekstrak HL.57F.258 (3) pada fase kloroform diperoleh luas area $91,04 \%$. Metabolit sekunder yang dihasilkan oleh kapang HL57F.258 mendekati Kloramfenikol dan Ampisilin atau menghasilkan senyawa aktif yang dapat menghambat pertumbuhan Escherichia coli ATCC 35218 dan Staphylococcus aureus ATCC 25923.

\section{KESIMPULAN DAN SARAN}

Diperoleh 2 isolat kapang endofit yaitu HL.46F.211 dan HL.57F.258 positif menghambat pertumbuhan Escherichia coli ATCC 35218 dan 3 isolat yaitu HL.48F.217, HL.53F.243 dan HL.57F.258 positif menghambat pertumbuhan Staphylococcus aureus ATCC 25923.

Hasil analisis senyawa antibakteri dengan KCKT menunjukkan bahwa senyawa aktif dari ekstrak kapang HL.46F.211 dan HL.57F.258 mempuyai nilai waktu retensi (Rt) mendekati antibiotik standar kloramfenikol dan Ampisillin. Khususnya HL.46F.211(1) pada fase air menghasilkan luas area $100 \%$ terhadap antibiotik standar Kloramfenikol dan HL.57F.258 (3) fase Kloroform menghasilkan luas area 91,04\% terhadap antibiotik standar Ampisillin.

\section{UCAPAN TERIMA KASIH}

Ucapan terima kasih disampaikan kepada Pimpinan Proyek Penelitian Bioteknologi yang telah memberikan dana dan kesempatan dalam melakukan penelitian. Disampaikan pula ucapan terima kasih kepada Saudara Bustan dan Saudari Nuryati serta semua pihak yang membantu kelancaran dalam kegiatan penelitian ini.

\section{DAFTAR PUSTAKA}

Bills, G.F. 1996. Isolation and analysis of endophytic fungal communities from woody plants. World Mycologia Journal: 31-65.

Bonjar, J.G., Fooladi, M.H., Mahdavi, M.J., \& Shahghasi, A. 2004. Broad-spectrum, A novel antibacterial from Streptomyces sp. Biotechnol 3: 126-130.

Brooks, G.F., Butel, J.S., \& Morse, S.F. 2001. Medical Microbiology. $2^{\text {th }}$ edition. New York: Mc. Graw Hill.

Carroll, G.C. 1988. Fungal endophytes in stems and leaves: From latent pathogen to mutualistic simbiont. Ecology 62: 2-9.

Carroll, G.C. 1991. Bey and pest detterence alternative strategies and hidden cost of endophytic microorganism in vascular plants. Di dalam: Andrew, J.H. \& Manamo, S.S. (eds.). Microbial Ecology of Leaves. Springer-Verlag.

Castillo, U.F., Strobel, G.A., Frod, E.J., Hess, W.M., Porter, H., Jensen, J.B., Albert, H., Robison, R., Condron, M.A., Teplow, D.B., Stevens, D., \& Yaver, D. 2002. Mumubicins wide-spectrum antibiotic produced by Streptomyces NRRL 30562 , endophytes on kennedia nigricans. Microbiology 148: 2675-2685.

Clay, K. 1988. Fungal endophytes of grasses: A devense mutualism between plants and fungi. Ecology 69(1): 10-16.

Desriani A.M. \& Lestari, Y. 2004. Screening of Stretomyces spp. producing $\beta$-laktamase inhibitory protein. Hayati 11: 8892.

El-Sayed, A.H.M. 1994. Production of penicillins and chepalosporins by fungi. Di dalam: The Mycota. Tokyo: Springer. Halaman 517.

Faeth, S. H. 2002. Are endophytic fungi defensive plant mutualism?. Journal Oikos 98: 25-36.

Gritter, R.J., Bobbitt, J.M., \& Schwarting, A.E. 1991. Pengantar Kromatografi. Bandung: Penerbit ITB.

Handayani, D.L. 2004. Mikrofungi Endofit Penghasil Antibakteri Penghambat Escherichia coli. Skripsi. Fakultas Biologi UGM. Yogyakarta: Universitas Gajah Mada.

Holler, U. 1999. Isolation, biological activity and secondary metabolite investigations of marine derived fungi and selected host sponges. Wihelmina. Carolo University. www.opus.tu bs.de/opus/volltexte/1999/40

Ingraham, J.L. \& Ingraham, C.A. 2000. Introductionary of Microbiology. Second edition. Washington: Brooks Cole.

Kahono, S. \& Arief, A.J. 2002. Kegiatan Penelitian Keanekaragaman Hayati di TNGH: Kerjasama LIPI-PHKA-JICA. Workshop Riew BCP-JICA.Jakarta. Halaman 10.

Khopkar S.M. 1990. Konsep Dasar Kimia Analitik. Jakarta: Penerbit UI

Madigan, M.T. Martinko, J. M., \& Parker, J. 2000. Brock Biology of Microorganism. New Jersey: Prentice Hall Inc. 
Neneng, L. 2000. Karakterisasi Senyawa Antibiotik Yang Resisten Terhadap Beta-laktamase Tipe TEM-1 dari Isolat ICBB 1171 Asal Ekosistem Air Hitam Kalimantan Tengah. Http:/ /www.icbb.org/indonesia/penelitian/penelitian01.htm

Petrini, D., Sieber, T.N., Toti, T., \& Viret, D. 1992. Ecology metabolite production and substrate utilization in endophytic fungi. Natural Toxin 1: 185-196.

Sanglard, D. 2001. Integrated Antifungal Drug Discovery in Candida albicans. Nature Biotechnology 19: 212-213.

Salle, B. S. 1961. Fundamentals Principles of Bacteriology. $5^{\text {th }}$ edition. Philadelphia: Mc. Graw Hill Book Co. Halaman 265.

Simanjutak, P., Melliawati, R., Soeksmanto, A., Parwati, T., \& Bustanussalam. 2002. Pengembangan bahan baku zat bioaktif antimalaria dari mikroba endofit tumbuhan obat Indonesia. Laporan Teknik Penelitian Puslit Bioteknologi-LIPI. Cibinong-Bogor.
Stahl, E. 1969. Thin Layer Chromatography: A Laboratory Hand Book. Translated by M.R.F. Ashworth. New York: SpringerVerlag. Halaman 101, 148.

Strobel, G.A., Dirkse, E., Sears, J., \& Markworth, C. 2001 Volatile antimocrobilas from Muscudor albus a novel endophytic fungus. Journal Microbiology 147: 2943-2950.

Sukara E, Melliawati, R., \& Saono,.S. 1992. Amylases production from Cassava by an indigenous yeast. J. Sci. Tech. Develop 9: 157-168.

Tan, R.X. \& Zou, W.X. 2001. Endophytes: a rich source of funcional metabolites. Journal Natural Product The Royal Society of Chemistry 18: 448-459.

Tjay, T.H. \& Raharja, K. 2002. Obat-obat Penting, Khasiat, Penggunaan, dan Efek Sampingnya. Jakarta: PT. Exel Media Komputindo. 